NBER WORKING PAPER SERIES

\author{
DID TEACHERS' RACE \\ AND VERBAL ABILITY MATTER \\ IN THE 1960's?: COLEMAN REVISITED
}

Ronald G. Ehrenberg

Dominic J. Brewer

Working Paper No. 4293

\author{
NATIONAL BUREAU OF ECONOMIC RESEARCH \\ 1050 Massachusetts Avenue \\ Cambridge, MA 02138 \\ March 1993
}

Irving M. Ives Professor of Industrial and Labor Relations and Economics at Comell University and Research Associate at the National Bureau of Economic Research (NBER), and Ph.D. candidate in Labor Economics at Comell University. Our research was supported by the William H. Donner Foundation and the Finance Center of the Consortium for Policy Research in Education (CPRE). CPRE is a consortium of the University of Southem California, Rutgers University, Comell University, Harvard University, Michigan State University, and the University of Wisconsin-Madison, and is funded by grant \#R1178G10O39 from the U.S. Department of Education, Office of Educational Research and Improvement. The views expressed here are solely the authors' and do not reflect the views of Comell, the NBER, the William H. Donner Foundation, CPRE, or the U.S. Department of Education. Without implicating them for what remains, we are grateful to numerous colleagues at Comell and around the nation for their comments on an earlier draft. The data set we used in our analyses will be deposited at the Interuniversity Consortium for Political and Social Research (ICPSR) within six months of our paper's acceptance for publication. This paper is part of NBER's research program in Labor Studies. Any opinions expressed are those of the authors and not those of the National Bureau of Economic Research. 


\title{
DID TEACHERS' RACE \\ AND VERBAL ABILITY MATTER \\ IN THE 1960's?: COLEMAN REVISITED
}

\begin{abstract}
Our paper reanalyzes data from the classic 1966 study Equality of Educational Opportunity, or Coleman Report. It addresses whether teacher characteristics, including race and verbal ability, influenced "synthetic gain scores" of students (mean test scores of upper grade students in a school minus mean test scores of lower grade students in a school), in the context of an econometric model that allows for the possibility that teacher characteristics in a school are endogenously determined.

We find that verbal aptitude scores of teachers influenced synthetic gain scores for both black and white students. Verbal aptitude mattered as much for black teachers as it did for white teachers. Finally, holding teacher characteristics other than race constant, black teachers were associated with higher gain scores for black high school students, but lower gain scores for white elementary and secondary students. Because these findings are for American schools in the mid-1960's, they do not directly apply to our contemporary experience. However, they do raise issues that should be addressed in discussions of hiring policies in American education.
\end{abstract}

\author{
Ronald G, Ehrenberg \\ ILR-Cornell University \\ Ithaca, NY 14853-3901 \\ (607) $255-3026$ \\ and NBER
}

\author{
Dominic J. Brewer \\ ILR-Comell University \\ Ithaca, NY 14853-3901 \\ (607) 255-3026
}




\section{Introduction}

Motivated by the poor academic performance and high drop-out rates of many minority elementary and secondary school students vis-a-vis their white counterparts, as well as the fact that the racial/ethnic distribution of public school faculty often does not reflect the racial/ethnic distribution of their students, many school districts have aggressively sought to increase their hiring of minority faculty. This policy has been pursued even in the face of a declining pool of minorities seeking to enter careers in education and evidence that new minority teachers tend to fail the National Teacher Examination at a higher rate than new white teachers. ${ }^{1}$ Confronted by fiscal stringency, many school districts have also begun to institute early retirement plans to encourage older, more experienced, and often white, teachers to retire, the reby creating vacancies for lower paid new, or relatively inexperienced, minority teachers.

These policies raise a host of issues. Minority teachers are thought by many to be more effective teachers of minority students because the former may serve as role models for, may interact better with, may have more favorable attitudes towards and higher expectations for, and may provide more positive feedback to, minority students. ${ }^{2}$ Ultimately, however, society must be concerned about minority teachers' impacts on the educational (test scores, completed schooling levels) and post-educational (labor market success) outcomes of both minority and white students. Only if minority teachers improve, or at least leave unchanged, the outcomes of both groups (as compared to what white teachers would generate) can minority recruitment policies in public education be judged pareto optimal in terms of their impacts on students. If they improve the outcomes for minority students but reduce the outcomes for white students, the debate over these policies 
will shift to their distributional (across student group) consequences. If minority teacbers are shown to have no impact on the outcomes for minority students and to adversely influence those for white students, the debate will shift to one over the importance society places on providing employment opportunities for minority teachers to belp remedy historical inequities and perceptions of current discrimination against potential minority teachers.

Of course, minority and white teachers differ, on average, on a number of dimensions other than race. They come from different socioeconomic backgrounds, have different levels of experience, have different degree levels, and tend to have received their degrees from different institutions. They also tend to score differently on standardized aptitude and achievement tests. While issues relating to the "cultural bias" in test scores have been raised, studies do suggest that students' academic performance is related, on average, to their teachers' performance on standardized tests. ${ }^{3}$ Comparisons of the effectiveness of minority and white teachers must control, if possible, for these other characteristics.

Research on the relative effectiveness of minority teachers has been conducted primarily by sociologists, psychologists, and educational researchers. Most studies have focused on teachers' attitudes, teachers' expectations, teachers' placement of students, and the feedback (positive and negative) that teachers provide students. ${ }^{4}$ Only a few have addressed educational outcomes and none has addressed subsequent labor market success. ${ }^{5}$ Many have been studies of a single school district and these typically failed to control for other teacher characteristics. Only a few studies used representative national data bases, only a few attempted to model the process by which teachers get assigned to schools, and 
none controlled for this process in the estimation of teacher effects. To our knowledge, none addressed whether the effects of teachers' verbal ability vary either with the race of the teachers or the race of the students they are teaching.

Our paper begins to address some of the issues we have raised, by reanalyzing data from the classic 1966 study Equality of Educational Opportunity, or Coleman Report. As we describe in the next section, these data permit us to estimate how, during the mid-1960s, the characteristics of teachers of different races (verbal aptitude, degree levels, years of experience) influenced an estimate of the change in test scores over a three grade level period, for students of different races. They also permit us to test whether controlling for the process by which teacher characteristics (including race) get assigned to different schools influences our estimated relationships.

After discussion of the Coleman Report in the next section, sections III and IV present our empirical analyses. The two final sections then discuss the significance of our findings and their implications for future research.

\section{The Coleman Report}

The Coleman Report represented an important step in educational research. Its statistical analyses, based on data from over 570,000 pupils, 60,000 teachers, and 4,000 principals, represented the beginning of the "educational production function" literature.

The methodological approaches used in the Coleman Report were severely criticized and numerous reanalyses of the data took place within a few years of the Report's publication. $^{6}$ Most social scientists, and public attention, focused on its conclusions 
concerning the extent of race segregation in schools and the importance of family background characteristics in explaining variations in student achievement. Less well known (or well remembered) is that the underlying data set contained information on teacher verbal ability (as measured by scores on a verbal aptitude test) and that the average verbal aptitude of teachers in a school was seen to be positively correlated with student test scores. Both the original Coleman Report and subsequent reanalyses of its data found this correlation and some researchers concluded that the correlation appeared stronger at higher grade levels. $^{7}$

The Coleman Report data appear to be unique among existing micro level data sets in that they contain a measure of individual teachers' verbal ability. One serious weakness of the data, however, is that they represent a "snapshot" at a single point in time and that only a current year test score measure exists for each student. Subsequent educational research by economists has stressed that to more fully control for unobservable student, family, and community characteristics that influence student achievement, one should relate school characteristics, including teacher ability levels, to student gain scores, or changes in test scores over time - not to student test score levels at a point in time. ${ }^{8}$

While all of the prior research that used the Coleman Report data estimated current year test score equations, the data do in fact contain information on third and sixth graders at each elementary school and ninth and twelfth graders at each high school. Moreover, one can identify the subset of third and sixth graders who spent their entire elementary school careers at a given elementary school and similarly identify the subset of twelfth graders who spent their entire high school careers at a given high school. Restricting one's attention to 
these subsets of student respondents, computing mean scores for each school by grade, and assuming that within a school, the unobservable characteristics don't vary across grades, one can compute "synthetic" gain scores as the difference between the mean test scores in the two grades for each school. For example, the difference between the mean test scores of sixth graders in a school and the mean test scores of third graders in a school at the survey date can be taken as an estimate of how much third graders in the school would learn if they remained in the school for three more years. ${ }^{9}$ In cases where the schools have a significant number of both white and black students, these gain scores can also be computed separately for each racial group..$^{10}$

These gain scores are used as dependent variables in the next section in the estimation of educational production functions in which the gain scores by school are related to student family, community, school, and teacher characteristics. Of primary interest to us will be the effect of the racial composition of teachers in a school and their verbal abilities on the gain scores of students of each racial group. ${ }^{11}$ Given prior mentioned concerns about the alleged "cultural bias" of tests, we also address whether increasing the verbal ability of teachers of each race has the same impact on the gain scores of students of different races.

While conceptually such an analysis is straightforward, an important statistical issue exists. Teachers are not randomly assigned to schools and school districts; teachers with higher test scores may be more easily attracted to higher paying districts, districts with smaller class sizes, and districts whose families are highly educated. Similarly, teachers may prefer to work with students who come from the same racial group or from similar 
socioeconomic backgrounds. To make sure that such nonrandom assignment does not lead to biased estimates of the effects of teacher characteristics on student gain scores, an instrumental variable approach and a "difference in differences" approach are employed in section IV to control for the process by which teachers and schools are matched. ${ }^{12}$

\section{Estimating Synthetic Gain Score Equations}

\section{A. Descriptive Statistics}

The Equality of Educational Opportunity (EEO) data tapes that we received from the National Archives contained data for third grade students at 2,499 schools, sixth grade students at 2,389 schools, ninth grade students at 930 schools and twelfth grade students at 787 schools. $^{13}$ We restricted our attention to the subset of elementary schools for which data were reported for both elementary grades and the subset of high schools for which data were reported for both secondary grades. We also required that data for each school were reported on all of the explanatory variables used in the analyses that follow, including the characteristics of teachers. ${ }^{14}$ All data were aggregated to obtain school level mean values for the entire sample, for white students at the subset of schools that had some white students in attendance, and for black students at schools that had some black students in attendance. $^{15}$

As Table 1 indicates, the restrictions left us with a maximum sample of 969 elementary schools and 256 high schools. ${ }^{16}$ Of the former, 799 had at least one white student in both grades and 514 had at least one black student in both grades. Of the latter, 178 had at least one white student in both grades and 183 had at least one black student in 
each grade. Because the elementary school sample sizes are so much larger, the majority of the analyses that follow use the elementary school data.

Students in each grade were administered verbal aptitude, nonverbal aptitude, reading and mathematics tests. The weighted (by number of students taking the tests) mean percentage of correct answers on the four tests across schools was 58.18 for third graders and 52.28 for ninth graders. The weighted mean synthetic gain scores, the mean for the sixth grade minus the mean for the third grade and the mean for the twelfth grade minus the mean for the ninth grade, were 1.55 and 0.90 , respectively.

At the elementary school level 31 percent of the students and 27 percent of the teachers were black, while at the high school level the comparable percentages were 29 and $25 .^{17}$ Elementary school teachers in the sample averaged close to 16 years of teaching experience, about 17 percent of them had earned at least a masters degree and, on average, they answered correctly slightly more than 75 percent of the questions on a verbal aptitude test that was administered to them. High school teachers were quite similar on their experience and their verbal aptitude scores, but over 34 percent of them had at least a masters degree.

Table 1 also summarizes these data separately for white students and for black students, indicating in each case how their teachers' characteristics varied by race. White students tended to have higher base year test scores and larger gain scores than black students at both the elementary and secondary levels. The typical white elementary school student was enrolled in a school in which about 6 percent of the students and 4 percent of the teachers were black, while the typical black elementary school student found 77 percent 
of his or her classmates and 71 percent of his or her teachers black. The respective values for high school students were quite similar.

Both white and black teachers' verbal aptitude scores tended to be higher if they were employed at schools in which white students were enrolled than if they were employed in schools in which black students were enrolled. In addition, white teachers' verbal aptitude scores were higher than black teachers' verbal aptitude scores in both types of schools, although at the high school level the difference at schools in which white students were enrolled was quite small. Experience and degree differences across the two types of schools and, within a type, across the two types of teachers were less uniform and were not always in favor of white teaches. For example, in both elementary and secondary schools at which white students were present, black teachers were more likely than white teachers to have advanced degrees. ${ }^{18}$

\section{B. Elementary School Analyses}

Estimates are presented in column (1) of Table 2 of synthetic gain score equations of the form,

$$
\text { GAIN }_{i}=\alpha_{0}+\alpha_{1} X_{i}+\alpha_{2} S_{i}+\alpha_{3} \text { BYTEST }_{i}+\alpha_{4} T_{i}+\epsilon_{i}
$$

Here $X_{1}$ represents a vector of characteristics of school i's students, their families, and the community in which the school is located; $S_{i}$ represents a vector of characteristics of the school; and $T_{1}$ represents a vector of characteristics of the school's teachers. BYTEST is the average test score of grade 3 students in the school and $\mathrm{GANN}_{i}$ is the difference 
between the average test score of grade 6 students in the school and the average test score of grade 3 students in the school.

Included in $X_{i}$ are the percentages of the school's students that are female (FEM), black (BLACKS), have no father or no mother in the home (FNHH, MNHH), have a telephone in the household (PHONE), and receive free lunches (FLNCH), the mean income of the families of the school's students (INCOME), the mean education levels of the fathers and mothers of the school's students (FED, MED), and whether the school is located in a central city (CITY), rural (RURAL), or suburban (the omitted category) area. ${ }^{19}$ The school characteristics are the number of books per pupil in the school's library (BOOKS) and the pupil/teacher ratio in the school (PUPT). Finally, the teacher characteristics are the proportion that are black (BLACKT), the mean years of teaching experience (EXP), the percentage with at least a masters degree (MA), and the mean verbal test score of teachers in the school (VERB). Since the schools in the sample vary considerably in size, the method of weighted least squares is used to obtain the estimates.

Gain scores prove to be higher in schools with a greater percentage of female pupils, a smaller percentage of black students, fewer families with only one parent in the household, more families with telephones, fewer families receiving free lunches, and higher parental education levels. Relative to suburban schools, gain scores are higher in rural schools and lower in central city schools. Higher pupil/teacher ratios are associated with lower gain scores. Finally, "regression to the mean" is present, as higher base year test scores are associated with lower gain scores. 
Of primary concern to us is the role that teacher characteristics play. In this model, increasing the proportion of black teachers by .1 is associated with a .4 decrease in the school's gain score. Teachers' experience is positively associated with the gain score, but teachers' degree level does not appear to matter. Crucially, higher verbal aptitude scores for teachers are associated with higher gain scores for students. If teachers' verbal aptitude scores could be increased by 10 percentage points, gain scores are predicted to be .9 points higher. The latter should be contrasted to a mean gain in the sample of 1.55 .

The remaining columns in Table 2 ascertain the sensitivity of these results to changes in the model's specification. While inclusion of the base year (third grade) test score on the right-hand side of equation (1) is justified because how much students learn over time depends on where they are starting from, there are well-known statistical problems that result. On the one hand, if the base year test score and the gain score are both influenced by a common set of variables and any of these variables are omitted from equation (1), then inclusion of BYTEST may lead to biased estimates of the coefficients of other variables in the model. ${ }^{20}$ On the other hand, if BYTEST measures students' true abilities with error, its coefficient will be biased towards zero and thus our estimate of the extent of regression to the mean overstated.

One way to handle this problem is to omit BYTEST from the model and see whether this substantially influences the other coefficients. This is done in column (2). While mean teacher experience is now no longer significant, teacher verbal ability is still positively, and the proportion of black teachers negatively, associated with a school's gain score. ${ }^{21}$ 
Does mobility of students into and out of a school influence the amount of learaing that goes on in the school? Column (3) adds as an explanatory variable the percentage of sixth grade students in a school that spent their entire elementary school careers in the scbool (STAY). This variable does not prove to be statistically significant and its inclusion does not substantially influence any of the other coefficients in the model (compare columns (1) and (3)).

Of course, as noted in the introduction, it would be desirable to confine the computation of the synthetic gain scores to students who had always remained in the same elementary school. This is done in columns (4) and (5) where the gain score is now computed as the mean test score for sixth grade students who spent their entire school career at the school minus the mean test score for third grade students who spent their entire careers in the school.22

The estimated associates between the proportion of black teachers and teachers' verbal aptitude scores and the synthetic gain scores in this restricted sample are quite similar to those found in the unrestricted sample. One new finding, however, is that the synthetic gain scores of these stayers are larger, the larger is the proportion of sixth grade students in the school who spent their entire careers at the school. Put another way, the more tumover there is in a school's student population, the lower the gain scores are for the students who remained at the school.

The analyses reported in Table 2 group all students together. They do not permit us to address an issue that is of key importance to us - whether a teacher's race and verbal ability differentially influence the academic achievement of students of different races. To 
address this issue, Table 3 reports estimates of selected coefficients from equations that were estimated separately for black and white students. In each case the synthetic gain score is now computed for each school using only data for students of the given race.

Columns (1) for the white and black student samples report coefficients from equations specified identically to column (1) in Table 2. In this model, a higher percentage of black teachers in a school is assaciated with a lower synthetic gain score for white students but is not associated with a higher gain score for black students. Teacher verbal ability is positively related to gain scores for both groups of students and the magnitude of the relationship is about the same. Teacher experience has a payoff only for white students and having more teachers with advanced degrees enhances learning for black students, but perversely lowers it for white students.

To estimate whether the effects of teacher verbal ability, experience and degree level vary for each group of students with the race of the teachers, expanded versions of the equation underlying columns (1), (3), and (5) of Table 2 were estimated that allowed for interactions. For example, in the case of column (1), the estimating equation became:

$$
\begin{aligned}
\operatorname{GAIN}_{\mathrm{ij}} & =\alpha_{0 \mathrm{j}}+\alpha_{\mathrm{ij}} \mathrm{X}_{\mathrm{ij}}+\alpha_{2 \mathrm{j}} \mathrm{S}_{\mathrm{i}}+\alpha_{3 \mathrm{j}} \mathrm{BYTEST}_{\mathrm{ij}} \alpha_{4 \mathrm{j}}\left(\mathrm{BLACKT}_{\mathrm{i}}^{*} \mathrm{~T}_{\mathrm{iB}}\right) \\
& +\alpha_{5 j}\left(1-\mathrm{BLACKT}_{\mathrm{i}}\right)^{*} \mathrm{~T}_{\mathrm{iw}}+\epsilon_{\mathrm{ij}}
\end{aligned}
$$

Here $j$, equal to 1 or 2 , indexes the black or white student equation and $T_{i B}\left(T_{i w}\right)$ is the vector of characteristics of black teachers (white teachers) in school i.

Selected coefficients from these models appear in columns (1w), (3w) and (5w) for white students and columns (1b), (3b), and (5b) for black students. The estimates in column 
(1) for each group come from equations that are restricted versions of the equations that underlie columns (1w) and (1b) and hence one can test for each group whether the restrictions are valid. Formal $F$ tests suggests they are not. ${ }^{23}$ That is, we can reject the bypotbesis that, for each group of students, the effects of all the teacher characteristics variables are the same for black and white teachers.

The results in this table are striking. In most specifications the percentage of students that are black does not affect either black or white students' gain scores. Higher verbal scores for black teachers are associated with higher gain scores for both black and white students. In contrast, white teachers' verbal scores matter only for white students. Higher white teacher experience levels are associated with higher gain scores for only white students and black teachers' experience levels do not appear to have any impact on either group of students' gain scores. Finally, while an increase in the percentage of black teachers in a school with at least a masters degree increases the gain scores of black students, an increase in the comparable percentage for white teachers again perversely is associated with lower gain scores. ${ }^{24}$

Given the importance of the findings on teacher race and verbal ability that we have uncovered so far, it is of interest to learn which particular test scores teacher verbal ability and race appear to influence. Table 4 presents selected coefficients from synthetic gain score equations that are identical to those found in column (1) of Table 2 and columns (1b) and $(1 w)$ of Table 3 , save that the gain scores and base year test scores are now for the four individual tests - verbal aptitude, reading, nonverbal aptitude, and mathematics. 
The top panel suggests that teacher verbal ability is positively associated with the synthetic gain scores for all four tests (although the effect on the math score is the smallest) and that the proportion of black teachers is negatively associated with gain scores for the first three tests. Increases in the proportion of black students in the school are also associated with lower gain scores on all four tests.

The bottom two panels of Table 4 present separate estimates for white and black students and, for each, allow the effects of teacher characteristics to vary by race. An important finding is that higher verbal aptitude levels for black teachers are associated with higher synthetic gain scores for both black and white students on all four tests. In contrast, higher verbal aptitude scores for white teachers appear to be associated with only higher verbal and nonverbal aptitude gain scores for white students.

\section{Secondary School Analyses}

Table 5 contains weighted least square estimates of synthetic gain score equations for the high schools in our EEO sample. The outcome variable is now the mean percentage of correct answers of twelfth grade students in the school on their group of tests minus the mean percentage of correct answers of ninth grade students in the school on their group of tests. Because the sample sizes are smaller, fewer coefficients than in the elementary school sample prove to be statistically significant and fewer analyses are reported.

In these high school data, higher verbal aptitude scores of teachers are associated, on average, with higher gain scores for white students, but not for black students. When teacher characteristics are broken down by race, white teachers' verbal aptitude scores appear to matter for both groups of students, but black teachers' verbal aptitude scores do 
not. Increasing the proportion of black teachers in a school with at least a masters degree is associated with higher gain scores for both black and white students, although again the proportion of white teachers with at least an MA degree is negatively associated with white students' gain scores.

There is also evidence that white students' gain scores are positively associated with the percentage of students in the school that are black and negatively associated with the percentage of teachers that are black. In contrast, while black students' gain scores are not related to the proportion of students in the school that are black, they do appear to be positively associated with the proportion of black teachers. That is, in the EEO data, other things held constant, black teachers do improve the gain scores of black students at the high school level.

\section{Can School and Teacher Characteristics be Treated as Exogenous?}

Differences in school or teacher characteristics are not randomly determined across schools. Families choose where to live, and hence their children's schools, based on their own preferences and resource constraints. ${ }^{25}$ Teacher characteristics depend upon factors such as the salaries teachers are offered, and the pecuniary and nonpecuniary characteristics of the community in which the school is located. ${ }^{26}$ These considerations suggest that failure to treat teacher and school characteristics as endogenous may lead to biased estimates of their affects. ${ }^{27}$ Yet to date, virtually all studies of teacher and school affects have treated these characteristics as exogenous. ${ }^{28}$ 
These biases might arise if the teacher and school characteristics used in the synthetic gain score equations (equations (1) and (2)) are correlated with the error terms in the equations due to an omitted variable problem. For example, suppose that we are interested in the effects of teachers' verbal aptitude, that we assume (for now) that teacher verbal aptitude actually does not influence gain scores, and that the omitted variable is a measure of the value that the parents of students place on education. Presumably parents who value education highly will invest more in their children at home (thus leading to higher gain scores) and will also reside in school districts that pay high salaries to attract and retain teachers with high verbal aptitude scores (if they believe, erroneously in our example, that high teacher verbal aptitude enhances learning). Other things held constant, estimation of equations (1) or (2) by least squares would yield a positive relationship between gain scores and teacher verbal aptitude even though we have assumed (for now) that the true relationship is zero.

The bias arises in our example because of the endogeneity of families' locational decisions coupled with our inability to fully control for unobserved variables that simultaneously influence students' gain scores and their families' locations (which in turn determined teachers' verbal aptitude). We address this problem in two ways below. First, we use an instrumental variable estimation method to obtain instruments for the school and teacher characteristics variables, conduct formal statistical tests to ascertain which of these characteristics can be legitimately treated as being exogenous and which must be treated as endogenous, and then reestimate the synthetic gain score equation using the original variables for the exogenous characteristics and the instruments for the endogenous 
characteristics. Second, we use a "difference in differences" method, differencing across black and white students at the same school, to eliminate unobserved "ixxed effects".

Appendix Table A2 summarizes the equations we estimated to generate instruments for the school and teacher characteristics variables. In each case, the actual value of these variables were regressed on a set of characteristics of the families of these students at the school, a broader set of characteristics of residents of the county or SMSA in which the school was located, and an estimate of the starting teacher salary in each school district. ${ }^{29}$ The county and SMSA variables were obtained from the 1965 City and County Databook and starting salaries were obtained from within-school district teacher salary equations that were estimated by us, using the individual teacher data from the EEO.

These equations were estimated primarily to obtain instruments for the school and teacher variables and they should not be thought of as structural equations. Nonetheless, two particular sets of findings warrant reporting. First, other things held constant, schools with a higher percentages of black students are associated in these data with fewer books per pupil, lower average teacher experience, and lower average teacher verbal aptitude. They also are associated with a higher student/teacher ratio, proportion of black teachers and percentage of teachers with at least a masters degree. Second, higher starting salaries for teachers are associated with more books per pupil, lower student/teacher ratios, fewer black teachers, higher average teacher experience, and higher verbal aptitude scores.

The instruments obtained from the coefficients in Appendix Table A2 were used to test whether the assumptions that all the teacher and school characteristics can be treated as exogenous are valid, using Durbin-Wu-Hausman specification tests in the following two- 
stage fashion. ${ }^{30}$ First, an expanded version of the model that appears in column (1) of Table 2 was estimated that included both the original values and the instruments for all six teacher and school characteristics variables. The coefficients of the instruments for MA and PUPT each had $t$ statistics that exceeded 1.9 in absolute value and a formal $F$ test suggested that one can reject the hypothesis that the vector of coefficients of the six instruments as a set are all zero, and hence that all of the school and teacher characteristics variables sbould be treated as exogenous. ${ }^{31}$ These tests imply that at least MA and PUPT should be treated as endogenous in the estimation of this gain score equation.

Second, a version of the model was estimated in which the instruments for MA and PUPT replaced the original values of these variables, but both the original values and the instruments for the other teacher and school characteristics (BOOKS, BLACKT, EXP, VERB) were included. None of the coefficients of the instruments for the latter four variables in this model had a $t$ statistic that exceeded 1.5 in absolute value and a formal $F$ test suggested that one can not reject the hypothesis that the entire vector of these latter four instruments' coefficients are all equal to zero. ${ }^{32}$ This implies that BOOKS, BLACKT, EXP, and VERB can be treated as exogenous in the estimation of the gain score equation.

As a result, the synthetic gain score equation found in column (1) of Table 2 was reestimated with instruments used only for PUPT and MA. A comparison of the coefficients of the school and teacher characteristics variables that were obtained when weighted least squares was used on the original data (column 1, Table 6) and when a weighted instrumental variable procedure was used with these instruments (column 2, Table 6) suggests that the proportion of black teachers continues to be negatively, and teachers' 
verbal aptitude positively, associated with the synthetic gain scores. Moreover, the magnitudes of the coefficients of the two variables are roughly the same in the two specifications. Hence, our findings about the roles that teacher ability and race play do not appear to be biased by endogeneity issues.

We note, however, that if one also treats BOOKS, BLACKT, EXP, and VERB as endogenous, the results in column 3 are obtained. While the estimated effect of teacher verbal ability increases substantially, the coefficient of the proportion of black teachers now switches sign and is statistically insignificant. Thus, our conclusion about the effects that black teachers had on students in the 1960's hinges on the accuracy of our specification tests. $^{33}$

An alternative approach is to attempt to eliminate the unobserved school specific variables by focusing on differences in the gain scores for white and black students in the same school..$^{34}$ If the effects of the unobserved variables on white and black students at a school are assumed to be identical, regressing the difference between the white and black gain scores on the observed explanatory variables provides consistent estimates of the differences between corresponding coefficients from the white student and black student equations. For example, the coefficient of teachers' verbal ability will be a consistent estimate of the difference between the impact of teachers' verbal ability on white students' gain scores and the impact of teachers' verbal ability on black students' gain scores.

This approach obviously reduces the information one can recover. For example, a positive coefficient for teacher verbal ability might imply that higher teacher verbal ability leads to higher gain scores for both white and black students (but larger gains for white 
students), higher gain scores for only white students, lower gain scores for only black students, or lower gain scores for both groups (but smaller declines in absolute value for white students). That is, it provides us only with information on relative effects and tells us nothing about the absolute effect of a variable on gain scores for either group. Nonetheless, given that it does provide consistent estimates, we report selected coefficients obtained using this approach in Table 7.

These estimates suggest that an increase in the proportion of black teachers in a school was associated with a decline in the gain scores of white students relative to those of black students in the school (column 1). They also suggest that an increase in teacher verbal ability in a school was associated with an increase in the gain scores of white students relative to those of black students in the school (column 1). Finally, they suggest that an increase in black teacher verbal ability in a school was associated with an increase in the gain score of white students relative to those of black students in the school (column 2).

\section{Simulations}

Did teachers' race and verbal ability matter in the 1960s? Our reanalysis of the EEO data suggest that the answer is yes! On balance, increases in the verbal aptitude scores of both black and white teachers were associated, other things held constant, with higher synthetic gain scores. On balance, increases in the proportion of black teachers in a school were associated, other things held constant, with lower gain scores for white students at both the elementary and secondary level and higher gain scores for black students at the secondary level. 
A number of simulations that are summarized in Table 8 provide the reader with estimates of the quantitative importance of these characteristics. These simulations make use of the estimates that were obtained separately for black and white students and, thus, that allowed the influence of teachers' characteristics to vary with the race of the teachers (Tables 3 and 5). To give the reader a sense of the magnitudes that follow, we note that the results in column 1 of Table 2 suggest that reducing class size by 10 students per teacher for elementary school students, would be associated with roughly a 0.8 point increase in the students' gain scores.

The mean proportions of black teachers in the sample were $.04(.03)$ for white and $.71(.77)$ for black elementary (secondary) school students, respectively. The first three simulations ask what the impact would have been on students if the proportion of black teachers had been 1 higher? Those reported in row 1 hold constant the mean values of black and white teachers' other characteristics (MA, EXP, VERB) at their sample values. However, since the mean values of black and white teachers' characteristics differed, especially for VERB, this first simulation provides no information on whether teacher skin color per se would matter if other teacher characteristics were the same. The simulations reported in rows 2 and 3 address this issue. The former assumes that all teachers have the mean sample value of black teachers' characteristics, while the latter assumes that all teachers have the mean sample value of white teachers' characteristics.

In fact, the three sets of simulations yield quite similar findings. Depending upon the particular elementary school equations used in the simulation, increasing the proportion of black teachers by .1 is estimated to reduce the synthetic gain scores of white elementary 
school students by roughly .7 to 1.2 points and to reduce the gain scores of black elementary school students by roughly 0 to .5 points. This should be contrasted to mean gain scores of 5.86 and -4.42 for the two groups, respectively. At the high school level, the increase would reduce the synthetic gain scores of white students by roughly .9 to 1.2 points, but increase the gain scores of black students by roughly .2 to .4 points. This should be contrasted to mean gain scores of 0.86 and -0.53 , respectively.

The mean verbal aptitude test scores of white elementary (high school) teachers and black elementary (high school) teachers were $81.13(81.17)$ and $73.54(80.20)$ respectively for white students and $78.76(76.62)$ and 64.03 (66.91) respectively for black students. The simulations reported in the fourth and fifth rows of the table ask what the impact on the synthetic gain scores would have been if all black teachers' verbal aptitude scores were increased by 10 points (row 4) and if all white teachers' scores were increased by 10 points (row 5). Given that white teachers taught primarily white students and black teachers taught primarily black students in the 1960 s, one should expect that improving only the verbal test scores of teachers of one race would influence primarily the gain scores of students of that race. This in fact occurs.

Improving the verbal aptitude scores of black teachers by 10 points is estimated to increase the synthetic gain scores of white elementary school students by roughly .14 points and of black elementary school students by roughly .9 points. Similarly increasing the verbal aptitude scores of white elementary school teachers by 10 points is estimated to increase the synthetic gain scores of white elementary students by between .24 and .50 points, but to have very little, or even a small negative effect, on black elementary school students' scores. At 
the high school level, neither white nor black students gains scores are predicted to change very much in response to either a change.

\section{Concluding Remarks}

What conclusions should one come away with from our findings? Teacher race and verbal aptitude did matter in the 1960 s in the sense that both were associated with synthetic gain scores! Verbal aptitude scores of teachers nationwide have declined substantially during the last two decades. ${ }^{35}$ If one adds a quadratic term in ability to our gain score equation, one finds that the marginal affect of ability increases as ability declines, so that the payoff to improving teachers' verbal scores probably is even higher today. ${ }^{36}$

We must caution, however, that our results are for synthetic gain scores in the mid1960s. Synthetic gain scores, especially for the high school data, are dependent on drop-out rates. Other things equal, assuming the drop-outs come from the lower tail of the test score distribution, the higher the drop-out rate in a school between the ninth and twelfth grades, the higher the twelfth grade score will be and thus the larger the gain score will be. Put another way, our results may be subject to a form of selection bias. While no data exist on drop-out rates in the EEO, results we report elsewhere based on analyses of data from High School and Bevond suggest that teacher race and a proxy for teacher ability, do not influence a student's drop-out probability, so perhaps this is not a problem. ${ }^{37}$

Changes in student test scores over their school careers are not the sole outcome of interest. Do teacher verbal aptitude and race influence college-going behavior, college completion rates, or post-educational labor market outcomes? Do they influence 
noneconomic outcomes such as attitudes students hold towards individuals from other racial groups? These questions can not be answered with the EEO data, although one recent study on a related topic did suggest that school quality measures do affect labor market outcomes. 38

The racial and ethnic distributions of students and teachers are different today than they were 28 years ago when the EEQ survey was undertaken. So perhaps, are the attitudes about and expectations of black and white students and teachers towards members of the other race. Although our reanalyses of the EEQ data found that increasing the proportion of black teachers in a school, other things held constant, was associated with lower white student gain scores at both the elementary and secondary levels and higher black student gain scores only at the high school level, estimated relationships obtained from "educational production function" analyses are often not the same across studies and there is nothing that guarantees that these relationships will hold today. ${ }^{39}$ For example, one recent study of the actual gain scores between the second and sixth grades on reading and vocabulary tests for low-income black students in Gary, Indiana found that, holding other characteristics of teachers constant, black elementary school teachers did enhance the performance of these black students. ${ }^{40}$ Clearly, before drawing any policy conclusions it is necessary to replicate our analyses using more recent data. ${ }^{41}$

Conceptually, however, the issues we have raised should not be ignored. Minority teachers may, on average, improve the academic performance of black students but adversely influence the academic performance of white students today. Teacher verbal aptitude may matter today, on average, both for white and minority teachers. To the extent 
that the latter tend to have lower test scores, hiring minority teachers with lower verbal aptitude scores than white teachers may adversely affect the gain scores of both minority and white students. The case for expanding the number of minority teachers in public education rests on distributive as well as efficiency considerations. However, contemporary empirical evidence of the type we have presented surely should be part of the policy debate. 


\section{Footnotes}

1. On the declining pool of potential minority teachers see Cole (1986), Irvine (1988), Berger (1990), and Zinn (1990). For evidence that minority teachers are more likely to fail the National Teachers Examination (NTE), and, in Texas, the Texas Educational Assessment of Minimum Skills Examination, see Cole (1986), Ferguson (1990), and Thernstrom (1991).

2. See, for example, Irvine (1988).

3. On the potential cultural bias of tests and the validity of the NTE see National Research Council (1989), Ayers and Qualls (1979), Ayers (1988), Haney et al. (1987), Darling-Hammond and Wise (1983), and Sheehan and Marcus (1978). Studies that show that teachers' "ability", as measured by test scores, does affect student academic achievement include Armor (1972), Boardman, et al. (1978), Coleman (1966), Ferguson (1990; 1991), Sheehan and Marcus (1977), and Strauss and Sawyer (1986). In contrast, Summers and Wolfe (1977) find no evidence that teachers' "ability" matters.

4. These studies include Aaron and Powell (1982), Aloia, Maxwell and Aloia (1981), Banks (1988), Barnes (1979), Baron (1985), Beady and Hansell (1981), Braun (1976), Brophy (1981), Brown, et al. (1970), Byalick and Bersoff (1979), Carew and Lightfoot (1979), Coates (1972), Cooper, et al. (1975), Cooper and Tom (1984), Cornbleth and Korth (1990), Dusek and Joseph (1983), Eaves (1975), Feldman (1986), Gottlieb (1964), Haller (1985), Heath (1971), Holiday (1985), Irvine (1985; 1986; 1990), Jackson and Cosca (1974), Leiter (1976), Mathis (1976), Meier, et al. (1989), Natriello and Dornbusch (1983), Simpson and Erickson (1983), Sizemore (1981), Tobias, et al. (1983), and West and Anderson (1976). 
5. See, for example, Alexander, et al. (1987), Bridge, et al. (1979), Crain and Mahard (1978), Crain, et al. (1982), Cunningham (1975), Darkenwald (1975), Farkas, et al. (1990), Ferguson (1990; 1991), Glick (1971), Maynor (1970), Murnane (1975), Obberg (1972), Pascarella, et al. (1979), Rossel and Hawley (1983), Sanders (1982), Sheehan and Marcus (1977), St. John (1971), Touliatos, et al. (1977), and Yando, et al. (1971).

6. See, for example, Bowles and Levin (1968), Cain and Watts (1970) and the set of papers published in Mosteller and Moynihan (1972).

7. See, for example, Coleman (1966), Armour (1972), Hanushek (1972), Jencks (1972). Thernstrom (1991) has recently reminded people of this finding.

8. See Hanushek (1986).

9. Students in each grade were administered a battery of subject and aptitude tests. For each subject, different tests were administered to students in each grade so that one can not infer anything about the absolute amount students in a school learn by comparing, say, the mean third grade and mean sixth grade test scores. However, one can infer something about how much students in a school were learning in relative terms by comparing gain scores across schools. So, for example, if the mean third grade score on a test was $80 \%$ in each of two schools and the mean sixth grade scores were $80 \%$ and $90 \%$ in the two schools, respectively, the implication is that the students learn more between the third and sixth grade in the second school.

10. A major finding of the Coleman Report was how segregated by race schools were in 1966. For example, almost $80 \%$ of all white pupils in the first and twelfth grades attended schools that were 90 to $100 \%$ white, while more than $65 \%(85 \%)$ of black students 
in the first (twelfth) grade attended schools that were between 90 and $100 \%$ black (Coleman, 1966, p. 3). In the research that follows, gain scores are computed by race for a school if at least one student of that race are present in the base year grade. Since weighted least square analyses are used, schools with only a few students from a racial group are given very little weight in the race-specific analyses.

11. While only a small fraction of white students were taught by black teachers in 1966 , a greater fraction of black students were educated by white teachers. For the nation as a whole, the average black elementary (secondary) student attended a school in which $35 \%$ (41\%) of the teachers were white (Coleman, 1966,p. 3).

12. Prior analyses of how teachers sort themselves across school districts and decide whether to remain in the profession have been undertaken. See, for example, Ferguson (1991), and Murnane and Olsen (1990). However, Ehrenberg and Brewer (1992) is the first study to treat teacher characteristics as endogenous in the estimation of educational production functions.

13. The EEO data tapes are very poorly documented and considerable effort had to be expended by us to "clean" the data. A data appendix, available from us on request, discusses a number of the problems we faced and the actions we took.

14. Although over 60,000 teaches were surveyed in the original EEO survey, the data set we received from the National Archive contained information on only 44,193 teachers and came with a notice that two teacher files were missing. When teacher data was missing, it appeared to be missing for all the teachers in a school and all of these schools are necessarily excluded from our analyses. This restriction alone reduced the total number of 
schools in the sample from about 4,000 to 2,075 . This implies that most of the schools that failed to report teacher data were relatively small.

15. Any school that enrolled both white and black students, will appear in both the white student and the black student samples. Test scores for students of other ethnicities/ races, primarily Native Americans, Hispanics, and Asian Americans, are used to compute the mean test scores in the overall sample, but not in the black or white samples.

16. Part of the reason for the small high school sample is that many ninth graders attended junior high schools and thus were not enrolled in schools with twelfth grades.

17. The high percentages of black students and teachers in our sample occur because black schools were over-sampled in the original EEO survey.

18. Requiring black teachers to have more education than white teachers at schools with white students may reflect either discrimination in hiring or a compensating differential for their lower test scores.

19. Family income data are not available in the EEO data. We computed the occupational distribution (at the one-digit level) of fathers in each school and then used this distribution and data on the 1970 median male earnings in each occupation in the cersus region (4) in which the school was located to obtain an estimate of family income of families in the school.

20. Appendix Table A 1 contains mean test score level equations for the four elementary and secondary grades that are specified similarly to column 1 of Table 2 . While these test level equations suffer from omitted variable bias (see the introduction), it is clear that many 
of the measured variables that influence the synthetic gain scores also influence the test score levels.

21. An alternative way to handle the problem is to treat BYTEST as endogenous, obtain an instrumental variable estimate for it, and then reestimate the gain score equation in column (1) using the instrumental variable. We obtained an instrument by regressing BYTEST on the characteristics of the school's students, their families and the community in which the school was located (the $X_{i}$ ) and similar variables for the larger county or SMSA in which the school was located. When the gain score equation was reestimated using this instrument, the coefficient of the instrument proved to be insignificant but the coefficients of PBLACK $(-6.281)$ and VERB (.066) were very similar to the corresponding coefficients found in column 1 of Table 2 and both remained statistically significant. Consequently, in what follows, we treat BYTEST as exogenous.

22. In some schools, either all students failed to report whether they spent their entire careers in the school or all students reported that they had not. Hence, the smaller sample sizes in columns (3) through (5).

23. For the white students sample, the computed statistic is $F(3,776)=5.87$ and for the black student sample it is $F(3,491)=7.93$. Both of these values exceed the .99 critical values of $F(3,120)$ or $F(3, \infty)$ of 3.95 and 3.78 , respectively.

24. One can not infer the effect of black teachers per se in these models from the coefficients of BLACKT alone since this variable also interacts with the other teacher characteristics (see equation (2)). We conduct simulations, however, using all of these characteristics and their coefficients in Section V. 
25. See Tiebout (1956).

26. See Ferguson (1991).

27. Evans, Oates, and Schwab (1992) make a related point in the context of estimating "peer group effects" on drop-out rates. While they treat peer group measures, such as the percentage of disadvantaged students in a school as endogenous, they do not explore the influence of teacher or school characteristics.

28. Ehrenberg and Brewer (1992) is the exception. Ferguson (1991) treats teacher and school characteristics as exogenous when he estimates district-level educational production functions, but then goes on to show how these characteristics vary with underlying socioeconomic and demographic variables.

29. We are grateful to Marshall Smith, Dean of Stanford's Graduate School of Education, for helping us to develop an algorithm to identify the county or SMSA in which each school in the EEO survey was located. The data appendix provides details.

30. See Russell Davidson and James M. MacKinnon (1993), pp.237-242 for a more formal treatment.

31. The computed $F$ statistic was $F(6,681)=6.56$ which exceeds the critical value of roughly 2.80 for rejecting the hypothesis at the .99 level.

32. The computed $F$ statistic was $F(4,683)=1.44$ which is less than the critical value of roughly 3.78 for rejecting the hypothesis at the .99 level.

33. Two other extensions warrant brief reporting here. First, when one eliminates the estimated starting salary in a district from the instrumental variable equations (on the grounds that it is endogenous), one obtains virtually identical results to those reported in 
Table 6 and the text. Second, when one repeats the analyses eliminating the base year test score from the gain score equations (on the grounds that it too may be correlated with unobserved variables), one again obtains a similar pattern of results. That is, DurbinHausman-Wu tests suggest that only BOOKS, PUPT, and MA should be treated as endogenous and the estimated VERB and BLACKT coefficients obtained from such a specification are very similar to those obtained in column 2 of Table 2.

34. We are grateful to John Pencavel for suggesting this idea to us.

35. See Murnane, et al. (1991), Chapter 2.

36. When VERB squared is added to the model specified in column 1 of Table 2 and then the expanded equation reestimated, the coefficients of VERB and VERB squared, respectively become, with the absolute values of their $t$ statistics in parentheses, $.366(2.5)$ and -.002 (1.9). Although the marginal affect of VERB declines as aptitude increases in this model, it remains positive until VERB reaches 91.5 .

37. Ehrenberg and Brewer (1992).

38. See Card and Krueger (1992).

39. See Hanushek (1986).

40. Hanushek (1992).

41. The data used by Ferguson (1991) on Texas school districts would be extraordinarily valuable if characteristics of teachers and students by race/ethnic group for each district could be made available. 


\section{References}

Aaron, Robert and Glenn Powell. "Feedback Practices as a Function of Teacher and Pupil Race During Reading Group Instruction," The Joumal of Negro Education 51(1) (1982): 5059.

Alexander, Karl L, Doris R. Entwisle and Maxine Thompson. "School Performance, Status Relations, and the Structure of Sentiment: Bringing Teacher Back In," American Sociological Review 52 (October 1987): 665-682.

Aloia, Gregory, James A Maxwell and Stephan D. Aloia. "Influence of a Child's Race and the EMR Label on Initial Impressions of Regular Classroom Teachers, " American Journal of Mental Deficiency 85(6) (1981): 619-623.

Armor, David J. "School and Family Effects on Black and White Achievement: A Reexamination of the USOE Data," in Mosteller and Moynihan, Eds., On Equality of Educational Opportunity (New York: Random House, 1972).

Ayers, Jerry B. and Glenda S. Qualls. "Concurrent and Predictive Validity of the National Teacher Examination," Journal of Educational Research 73(2) (1979): 86-92.

Ayers, Jerry B. "Another Look at the Concurrent and Predictive Validity ofthe National Teacher Examinations," Journal of Educational Research 81(3) (January-February 1988): 133-137.

Banks, James A. "Ethnicity, Class, Cognitive, and Motivational Styles: Research and Teaching Implications," Journal of Negro Education 57(4) (1988): 452-466.

Barnes, Willie J. "Teachers in Desegregated High Schools in Texas," Integrated Education 97 (January-April 1979): 25-26.

Baron, Reuben M., David Y.H. Tom and Harris M. Cooper. "Social Class, Race and Teacher Expectations" in Jerome B. Dusek (Ed.), Teacher Expectancjes, 1985.

Beady, Charles J., Jr. and Stephan Hansell. "Teacher Race and Expectations for Student Achievement," American Educational Research Journal 1(2) (Summer 1981): 191-206.

Berger, Joseph. "Pessimism in Air as Schools Try Affirmative Action," New York Times, February 27, 1990: B1. 
Boardman, Anthony E., David A. Horowitz and Anne Lloyd. "Varjables Affecting the Learning of Inner City Children" in G. Gappert (Ed.), Urban Schools in Urban Systems, Selected Papers (Fall 1978).

Bowles, S. and H. Levin. The Determinants of Scholastic Achievement: An Appraisal of Some Recent Evidence," Journal of Human Resources III (Winter 1968): .

Braun, Carl. "Teachers Expectations: Sociopsychological Dynamics, ${ }^{\text {Review of Educational }}$ Research 46(2) (Spring 1976): 185-213.

Bridge, R. Gary, Charles M. Judd and Peter R. Moock. The Determinants of Educational Outcomes: The Impact of Families. Peers, Teachers, and Schools (Cambridge, MA: Ballinger Publishing Company, 1979).

Brophy, Jere. "Interactions of Male and Female Students with Male and Female Teachers" in Louise Cherry Wilkinson and Cora B. Marrett (Eds.), Gender Influences in Classroom Interaction (New York: Academic Press, Inc., 1985), 115-142.

Brown, William E., Tyrone L. Payne, Conard Lankewich and Lionel L. Cornell. "Praise, Criticism and Race," The Elementary School Joumal (April 1970):373-377.

Byalick, Robert and Donald N. Bersoff. "Reinforcement Practices of Black and White Teachers in Integrated Classrooms," Journal of Educational Psychology 66(4) (1979): 473 480.

Cain, Glen and Harold Watts. "Problems in Making Policy Inferences From the Coleman Report," American Sociological Review 35 (1970): 228-242.

Card, David and Alan B. Krueger. "Does School Quality Matter? Returns to Education and Characteristics of Public Schools in the United States, "Journal of Political Economy 100 (February 1992): 1-40.

Carew, Jean V. and Sara Lawrence Lightfoot. Beyond Bias (Cambridge, MA: Harvard University Press, 1979), 69-101.

Coates, Brian. "White Adult Behavior Toward Black and White Children," Child Development 43 (1972): 143-154.

Cole, Beverly. "The Black Educator: An Endangered Species," Journal of Negro Education 55(3) (1986): 326-335.

Coleman, James. Equality of Educational Opportunities (Washington, DC: U.S. Office of Education, 1966). 
Cooper, Harris M. and David Y.H. Tom. Teacher Expectation Research: A Review with Implications for Classroom Instruction," The Elementary School Journal 85(1) (September 1984): $77-89$.

Cooper, Constance Carter. "Implications of the Absence of Black Teachers/Administrators or Black Youth," Joumal of Negro Education 57(2) (1988): 123-124.

Cooper, Harris, Reuben Baron, and Charles A Lowe. "The Importance of Race and Social Class Information of Expectancies About Academic Performance," Joumal of Educational Psychology 67(2) (1975): 312-319.

Combleth, Catherine and Willard Korth. Teacher Perceptions and Teacher-Student Interaction in Integrated Classrooms, "Journal of Experimental Education 58 (1990), 259. 263.

Crain, Robert and Rita Mahard. "Desegregation and Black Achievement: A Review of the Research," Law and Contemporary Problems 42 (1978): 17.56 (1978b).

Cunningham, William G. "The Impact of Student-Teacher Pairings on Teacher Effectiveness," American Educational Research Association 12(2) (Spring 1975): 169-189.

Darkenwald, Gordon G. "Some Effects of the 'Obvious Variable': Teacher's Race and Holding Power with Black Adult Students, "Sociology of Education 48 (Fall 1975): 420-431.

Darling-Hammond, Lisa and A.E. Wise. "Teaching Standards, or Standardized Teaching?" Educational Leadership 41 (1983): 66-69.

Davidson, Russell and James G. Mackinnon. Estimation and Inference in Econometrics (New York: Oxford University Press, 1993).

Dusek, Jerome B, and Gail Joseph. "The Bases of Teacher Expectancies: a Meta-Analysis," Joumal of Educational Psychology 75(3) (1983): 327-347.

Eaves, Ronald C. "Teacher Race, Student Race, and the Behavior Problem Checklist," Journal of Abnormal Child Psychology 3(1) (1975): 1-9.

Ehrenberg, Ronald G. and Dominic J. Brewer. "Do School and Teacher Characteristics Matter?: Evidence From High School and Beyond," ILR-Comell Institute for Labor Market Policies Working Paper No. 7 (December 1992).

Evans, William N., Wallace E. Oates and Robert M. Schwab. "Measuring Peer Group Effects: A Study of Teenage Behavior," Journal of Political Economy 100 (October 1992): 966-991. 
Farkas, George, Robert Grobe, Daniel Sheehan, and Yuan Shuan. "Cultural Resources and School Success: Gender, Ethnicity, and Poverty Groups Within an Urban School District" American Sociological Review 55 (February 1990): 127-142.

Feldman, Robert S. (Ed.). The Social Psychology of Education: Current Research and Theory (New York: Cambridge University Press, 1986).

Ferguson, Ronald F. "Racial Patterns in How School and Teacher Quality Affect Achievement and Earnings," Challenge: A Journal of Research on Black Men (December 1990).

Ferguson, Ronald F. "Paying for Public Education: New Evidence on How and Why Money Matters," Harvard Journal on Legislation 28 (1991): 465-488.

Glick, Irwin. "Does Teacher's Skin Color Matter?" Integrated Education (SeptemberOctober 1971): 26-30.

Gottlieb, David. "Teaching and Students: The Views of Negro and White Teachers," Sociologv of Education 37 (1964): 345-353.

Haller, Emil. "Pupil Race and Elementary School Ability Grouping: Are Teachers Biased Against Black Children?" American Educational Research Journal 22(4) (Winter 1985): 465 483.

Haney, Walter, George Madaus and Amelia Kreitzer. "Charms Talismanic: Testing Teachers for the Improvement of American Education," Review of Research in Education 14 (1987): 169-238.

Hanushek, Eric. "The Economics of Schooling," Journal of Economic Literature 24 (September 1986): 1141-1176.

Hanushek, Eric. Education and Race: An Analysis of the Educational Production Process (Lexington, MA: Lexington Books, 1972).

Hanushek, Eric. "The Trade-Off Between Child Quality and Quantity," Journal of Politica! Economy 100 (February 1992): 84-118.

Heath, Robert W. "The Ability of White Teachers to Relate to Black Students and to White Students," American Educational Research Journal 8(1) (January 1971): 1-10.

Holiday, Bertha Garrett. "Differential Effects of Children's Self-Perceptions and Teachers' Perceptions on Black Children's Academic Achievement," Journal of Negro Education 54(1) (1985): 71-81. 
Irvine, Jaqueline Jordan, Teacher Communication Patterns as Related to the Race and Sex of the Student," Journal of Educational Research 78 (1985): 338-345.

Irvine, Jaqueline Jordan. "An Analysis of the Problem of Disappearing Black Educators," The Elementary School Journal 88(5) (May 1988): 503-513.

Irvine, Jaqueline Jordan. Teacher-Student Interactions: Effects of Student Race, Sex, and Grade Level," Journal of Educational Psychology 78(1) (1986): 14-21.

Jackson, Gregg and Ceclia Cosca. The Inequality of Educational Opportunity in the Southwest: An Observational Study of Ethnically Mixed Classrooms, "American Educational Research Journal 11(3) (Summer 1974): 219-229.

Jencks, Christopher P. "The Coleman Report and the Conventional Wisdom" in Mosteller and Moynihan, Eds., On Equality of Educational Opportunity (New York: Random House, 1972).

Leiter, Kenneth C.W. "Teachers' Use of Background Knowledge to Interpret Test Scores," Sociology of Education 49 (January 1976): 59-65.

Mathis, Dolores Walker. "Differences in Teacher Interaction With Afro-American and Anglo-American Students in the Same Classroom," Dissertation Abstracts InternationalHumanities and Social Sciences 36(9) (March 1976): 5950A.

Maynor, Waltz. "Academic Performance and School Integration: A Multi-Ethnic Analysis" (Durham, NC: Duke University, Doctoral Dissertation, 1970).

Meier, Kenneth J., Joseph Stewart, Jr. and Robert E. England. Race, Class, and Education: The Politics of Second-Generation Discrimination (Madison, WI: University of Wisconsin Press, 1989).

Mosteller, Frederick and Daniel P. Moynihan, Eds. On Equality of Educational Opportunity (New York: Random House, 1972).

Murnane, Richard J. The Impact of School Resources on the Learning of Inner City Children (Cambridge, MA Ballinger Publishing Co., 1975).

Murnane, Richard J. and Randy Olsen. "The Effects of Salaries and Opportunity Costs on Length of Stay in Teaching," Journal of Human Resources 25 (Winter 1990): 106-124.

Murnane, Richard J., el al. Who Will Teach? Policies That Matter (Cambridge, Mass.: Harvard University Press, 1991). 
National Research Council. Faimess in Employment Testing (Washington, DC: National Academy Press, 1989).

Natriello, Gary and Sanford M. Dormbusch. "Bringing Behavior Back In: The Effects of Student Characteristics and Behavior on the Classroom Behavior for Teachers," American Educational Research Journal 20(1) (Spring 1983): 29-43.

Ohberg, Hjordis. "Does the Black Child Need a Black Teacher?" Integrated Education (March-April 1972): 27-28.

Pascarella, Ernest T., Harriet Talmage and Sue Pinzur. "Summative Analysis of Longitudinal Student Achievement Data in a Desegregated School District," presented at the American Educational Research Association Conference, San Francisco, April 1979.

Rossel, Christine H. and Willis D. Hawley. The Consequences of School Desegregation (Philadelphia, PA: Temple University Press, 1983).

Sanders, Jimy M. "Faculty Desegregation and Student Achievement (Santa Barbara, CA: University of California, Department of Sociology, 1982).

Sheehan, Daniel S. and Mary Marcus. "Teacher Performance on the National Teacher Examinations and Student Mathematics and Vocabulary Achievement," Journal of Educational Research 71 (1978): .

Sheehan, Daniel S. and Mary Marcus. "The Effects of Teacher Race and Student Race on Vocabulary and Mathematics Achievement," The Journal of Educational Research 70(3) (1977): 123-126.

Simpson, Adelaide W. and Marilyn T. Erickson. 'Teachers' Verbal and Nonverbal Communication Patterns as a Function of Teacher Race, Student Gender, and Student Race," American Educational Research Journal 20(2) (Summer 1983): 183-198.

Sizemore, Barbara. "Do Black and White Students Look for the Same Characteristics in Teachers?" Journal of Negro Education 50(1) (1981): 48-53.

Strauss, Rober and Sawyer. "New Evidence on Teacher and Student Competencies," Economics of Education Review 41 (1986).

Summers, Arita A. and Barbara L. Wolfe. "Do Schools Make a Difference?" American Economic Review 67(4) (September 1977): 639-652.

Thernstrom, Abigail. "Beyond the Pale," The New Republic, December 16, 1991: 22-24. 
Tiebout, Charles M. "A Pure Theory of Local Expenditure," Journal of Political Economy 64 (October 1956): 416-424.

Tobias, Sigmund, Mara Zibrin and Cindy Menell. "Special Education Referrals: Failure to Replicate Student-Teacher Ethnicity Interaction," Joumal of Educational Psychology 75(5) (1983): 705-707.

Touliatos, John, Byron, Lindholm, Amy Rice. "Interaction of Race with Other Variables on Achievement in School," Psychology in the Schools 14(3) (July 1977): 360-363.

West, Charles K and Thomas H. Anderson. The Question of Preponderant Causation in Teacher Expectancy Research," Review of Educational Research 46(4) (Fall 1976): 613-630.

Yando, Regina, Edward Zigler, Maxine Gates. The Influence of Negro and White Teachers Rated as Effective or Noneffective on the Performance of Negro and White Lower-Class Children," Developmental Psychology 5(2) (1971); 290-299.

Zinn, Laura. "In Search of Tomorsow's Minority Teachers," Business Week, May 7, 1990: 120. 
Table 1

Descriptive Statistles: Weighted Means (By School Size)

\begin{tabular}{|c|c|c|c|c|c|c|}
\hline & \multicolumn{3}{|c|}{ Eerrentary Scboots } & \multicolumn{3}{|c|}{ Heit Sctools } \\
\hline & $\begin{array}{c}\text { (IE) } \\
\text { All Schook }\end{array}$ & $\begin{array}{c}\text { (2E) } \\
\text { Thite Srudear }\end{array}$ & $\begin{array}{c}\text { (3E) } \\
\text { Beact Srudear }\end{array}$ & 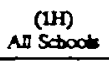 & $\begin{array}{c}\text { (2H) } \\
\text { While Sudeats }\end{array}$ & $\begin{array}{c}\text { (BH) } \\
\text { Bunt Studears }\end{array}$ \\
\hline BYTEST & 58.18 & 62.89 & 50.90 & 52.28 & $\$ 9.10$ & 38.93 \\
\hline GANN & 1.55 & 5.86 & -4.42 & 0.90 & 0.86 & -0.53 \\
\hline BLACKS & 31.12 & 6.63 & 77.48 & 29.24 & 6.32 & 82.06 \\
\hline BLACKT & .27 & .04 & .71 & 25 & .03 & .77 \\
\hline EXP & 15.81 & & & 14.89 & & \\
\hline MA & 17.69 & & & 34.23 & & \\
\hline VERB & 75.48 & & & 76.71 & & \\
\hline BEXP & & 17.37 & 1550 & & 13.95 & 14.94 \\
\hline BMA & & 22.17 & 18.35 & & 1272 & 25.28 \\
\hline BVERB & & 73.54 & 64.03 & & 80.20 & 66.91 \\
\hline WEXP & & 15.96 & 14.89 & & 14.71 & 14.49 \\
\hline HMA & & 17.56 & 17.83 & & 37.05 & 39.73 \\
\hline WVERB & & 81.13 & 78.76 & & 81.17 & 76.62 \\
\hline$P_{\exists}$ & & .38 & .90 & & .42 & $\pi$ \\
\hline $\mathbf{P}_{\mathbf{w}}$ & & .92 & .62 & & .92 & 55 \\
\hline $\mathrm{x}$ & $\$ 69$ & 799 & 514 & 266 & 178 & 183 \\
\hline
\end{tabular}

where

BYTESI

mean percentage of correct answers of third grade students in the school on the group of tests (ninth grade for high shools)

GAIX mean perentage of correct answers of sixth grade sludents in the school on the group of sixth grade lesis minus the mean perenlage of correct answers of third gade students in the school on the group of third grade tests (twelfth and ninth grodes for high whools)

BLACKS percentage of biack sludents in the third and sixth grades in the school (ninth and raelfih for high school)

BLACKT proporion of black teachers in the school

EXP mean years of teaching experience of teachers in the school

MA mean percentage of teschers in the school with at least a masier's degree

VERB mean persentage of cortecl answers of teachers in the school on the vertal lest

BEXP )

BMA I mean values for black teachers in schools with positive number of black teachers in the sample

BVERB ;

WEXP )

WMA I

WVER ?

$P_{\mathrm{B}} \quad$ proportion of schools with al leasl one black leacher

$P_{w} \quad$ proporion of cchools wilh al least one white leacher

Ni number of schools

Soure: Aushor' compulations from the Equality of Edugalional Opporunity survey data upes. 
Table 2

School Level Spabetic Gais Soore Bquationec Grades 3 i bo

(abolute value $t$ catistios)

\begin{tabular}{|c|c|c|c|c|c|}
\hline & \multicolumn{3}{|c|}{ All Srudents } & \multicolumn{2}{|c|}{ Srodeats tho Never Cunged Sctools } \\
\hline & (1) & (2) & (3) & (4) & (5) \\
\hline INTER & $11.483(3.8)$ & $-13.067(3.9)$ & $10.260(3.2)$ & $12.174(3.9)$ & $9.771(3.0)$ \\
\hline FEM & $.059(3.1)$ & $.067(2.9)$ & $.050(3.1)$ & $.043(3.0)$ & $.042(2.9)$ \\
\hline BLACKS &. $.050(5.8)$ & $-.011(0.9)$ & $-.057(55)$ & $-.083(65)$ & $-.081(6.3)$ \\
\hline FNHH & $.062(3.3)$ & $.029(1.3)$ & $-.061(3.1)$ & $-.037(2.1)$ & $.037(2.1)$ \\
\hline MNHH & $-.243(9.0)$ & $-.194(65)$ & $-.242(8.8)$ & $-.109(4.2)$ &. $.105(4.0)$ \\
\hline PHONE & $.100(7.5)$ & $.051(3.2)$ & $.098(7.2)$ & $.123(9.2)$ & $.122(9.2)$ \\
\hline INCOME & $.100(0.9)$ & $.229(1.0)$ & $223(1.1)$ & $.277(15)$ & $344(1.9)$ \\
\hline FLNCH & $-.029(2.6)$ & $-.008(0.6)$ & $-.029(2.6)$ & $-.026(2.0)$ & $-.024(1.9)$ \\
\hline FED & $1.079(4.7)$ & $501(1.8)$ & $1.102(4.8)$ & $.7 \%(4.0)$ & $.791(4.0)$ \\
\hline MED & $.358(1.3)$ & $.046(0.1)$ & $317(1.1)$ & $534(2.2)$ & $5.37(2.2)$ \\
\hline बIY & $.894(1.9)$ & $1.062(1.9)$ & $-876(1.8)$ & $-.67(1.2)$ & $.395(0.7)$ \\
\hline RURAL & $1.080(2.3)$ & $1.018(1.8)$ & $1.052(2.2)$ & $.915(1.8)$ & $.809(1.6)$ \\
\hline BOOKS & $.010(0.3)$ & $.015(0.3)$ & $.012(0.3)$ & $.013(0.3)$ & $.012(0.3)$ \\
\hline PLPT & $-.081(2.3)$ & $.002(0.0)$ & $-.076(2.2)$ & $-.076(2.0)$ & $-.061(1.6)$ \\
\hline STAY & & & $.009(1.0)$ & & $.030(2.7)$ \\
\hline BYTEST &. $.638(20.4)$ & & $-.634(20.0)$ & $-.653(19.9)$ & $-.656(20.0)$ \\
\hline $\mathrm{BLACKT}$ & $4.195(3.8)$ & $-5.956(4.9)$ & $4.452(3.9)$ & $4.226(3.0)$ & 4.481 (3.2) \\
\hline EXP & $.068(2.0)$ & $.023(0.5)$ & $.063(1.8)$ & $.058(15)$ & $.046(1.2)$ \\
\hline MA & $-.004(0.3)$ & $.007(0.5)$ & $-.003(0.3)$ & $-.001(0.1)$ & $-.001(0.1)$ \\
\hline VERB & $.093(4.1)$ & $.063(2.4)$ & $.096(4.2)$ & $.076(3.1)$ & $.081(3.2)$ \\
\hline$n$ & 969 & 969 & 953 & 928 & 928 \\
\hline $\overrightarrow{R^{2}}$ & .728 & .616 & .727 & .698 & .700 \\
\hline
\end{tabular}

- Each student's test score is the simple average of the percentage of correct answers the student received on verbal, nonverbal, reading, and mathematics tests.

'Weighted least squares regressions. The weight used is $\left[\left(N_{3} \times N_{g} /\left(N_{3}+N_{3}\right)\right]\right.$ where $N_{3}\left(N_{0}\right)$ is the number of third (sixth) grade students taking the test in the school. 
Table 2 (contlnued)

where:

DNTER intercept term

FEM

percentage of the school's students that are female

BLACKS percentage of the school's students that are black

FNHH percentage of the school's students without a father in the bousehold

MNHH percentage of the school's students without a mother in the bousebold

PHONE percentage of the school's students with a telephone in the bousehold

INCOME mean income of the families of the school's students (in thousands)

FLNCH percentage of the school's students that receive free lunches

FED

mean years of education of fathers of the school's students

MED

meas years of education of mothers of the school's students

CITY

$1=$ central siry school, $0=$ ocher

RURAL $\quad 1=$ rural school, $0=$ other

BOOKS number of books in the school's library (000's) per pupil

STAY

percentage of sixth grade students who have not changed schools since the first grade

BYTEST mean grade 3 test score (percentage of correct answers) in the school

BLACKT proportion of black teachers in the scbool

PUPT pupils per teacher in the scbool

EXP mean years of experience of teachers in the school

MA percentage of teachers with at least a master's degee in the school

VERB mean verbal test score of teachers in the school

Source: Authors' computations from the Equality of Educational Opportunity survey data tapes. 
Tabo 3

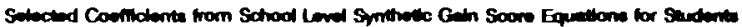

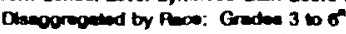

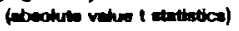

\begin{tabular}{|c|c|c|c|c|c|c|c|c|}
\hline & \multicolumn{4}{|c|}{ Whis Suxderts } & \multicolumn{4}{|c|}{ 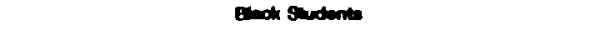 } \\
\hline & (1) & (1w) & $B(B)$ & (5w) & (1) & (16) & (Bt) & (D) \\
\hline BLACKS & $-.017(1.2)$ & $-.018(1.2)$ & $.018(1.2)$ & $-.055(2.5)$ & $.025(1.5)$ & $.013(0.7)$ & $.021(1.1)$ & $.008(0.2)$ \\
\hline BLACKT & $-15.737(8.4)$ & $-33.416(4.2)$ & $-30.863(3.6)$ & $-27.592(2.5)$ & $.1 .804(1.2)$ & $-12.975(1.9)$ & $-15.741(2.2)$ & $-17.361(1.9)$ \\
\hline EXP & $.111(3.6)$ & & & & $.024(0.4)$ & & & \\
\hline MA & $-.039(3.6)$ & & & & $.052(2.7)$ & & & \\
\hline VERB & $.060(3.3)$ & & & & $.086(2.5)$ & & & \\
\hline BTEXP & & $-.220(1.0)$ & $-.229(1.0)$ & $-.224(0.6)$ & & $.008(0.1)$ & $.036(0.4)$ & $.002(0.1)$ \\
\hline ВTMA & & $.070(1.0)$ & $.098(1.3)$ & $.138(1.5)$ & & $.005(4.3)$ &.$\infty 80(3.8)$ & $.004(3.5)$ \\
\hline BTVEAB & & $.378(3.6)$ & $.352(3.2)$ & $.301(2.1)$ & & $.134(3.2)$ & $.137(3.2)$ & .112 (2.2) \\
\hline WTEXP & & $.111(3.6)$ & $.087(2.6)$ & $.070(1.7)$ & & 014 p.1) & $-010(0.1)$ & $.000(0.5)$ \\
\hline WTMA & & $-.046(4.5)$ &. $.048(4.6)$ & $-.048(3.7)$ & & $.087(2.3)$ & $.008(1.5)$ & -045 p.n \\
\hline WTVERB & & $.047(1.9)$ & $.052(2.1)$ & $.025(0.9)$ & & $.010(0.2)$ & $-013(0.1)$ & $-0.080 . n$ \\
\hline $\mathbf{N}$ & 799 & 799 & 741 & 705 & 514 & 514 & 438 & 396 \\
\hline $\bar{R}^{2}$ & .433 & .448 & .364 & .617 & .584 & .617 & .025 & .501 \\
\hline
\end{tabular}

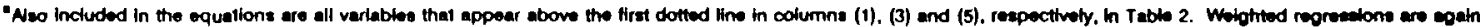
employed with the woighis now corresponding to the numbers of students in exch reciel group in the grades in the schoot.

whore

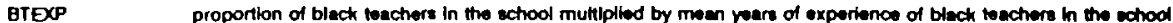

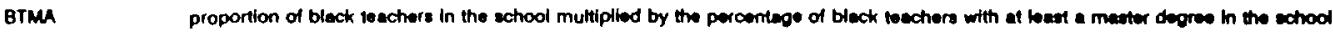

BTVERB proportion of black vachers in the school multiplied by the mean bleck wactier verbal test score in the schood

WTEXP

WTMA

WTVERB I

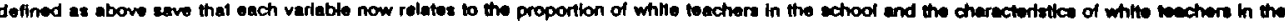
school 


\section{Tabie 4}

Selected Coefficients trom School Level Synthetic Galo Score Equations:

Grades 3 to 6: Individual Tests"

(absolute value $t$ statjstics)

Verbal Test

All Students

BLACK
BLACK
EXP
MA

VERB

White Students

BLACKS

BLACKT

BTEXP

BTMA

BTVERB

WTEXP

WTMA

WTVERB

$-.083(6.8)$
$-5.292(4.0)$
$.131(3.2)$
$-.000(0.0)$
$.114(4.2)$

$.042(2.4)$

$-34.463(3.6)$

. $.178(0.7)$

$.122(1.5)$

$350(2.8)$

$.155(4.3)$

$-.056(4.5)$

$.072(2.5)$

$.015(0.7)$

$.19 .516(2.4)$

.133 (1.4)

$.127(4.6)$

$.164(3.2)$

$.039(0.3)$

$-.088(1.8)$

$.016(0.2)$

$-.084(3.9)$
$-4.084(3.3)$
$.102(2.7)$
$-.005(0.4)$
$.082(3.3)$

$.009(0.5)$

-32.748 (3.5)

$.251(0.9)$

$.071(0.9)$

$366(3.0)$

$.150(4.0)$

$.047(3.7)$

$.039(1.3)$
$-.040(3.3)$

$-4.921(3.8)$

$.005(0.1)$

$.010(0.8)$

$.133(5.0)$
Matb Test

$-.110(9.1)$

$.626(0.5)$

$.104(2.6)$

$-.020(1.6)$

$.049(1.9)$

\section{Black Students}

$\begin{array}{lrrrr}\text { BLACKS } & .015(0.7) & .020(1.0) & .019(0.9) & . .009(0.5) \\ \text { BLACKT } & .19 .516(2.4) & -9.146(1.2) & -17.256(2.1) & -7.283(0.9) \\ \text { BTEXP } & .133(1.4) & .004(0.0) & .074(0.8) & .143(1.6) \\ \text { BTMA } & .127(4.6) & .099(4.0) & .100(3.7) & .051(2.0) \\ \text { BTVERB } & .164(3.2) & .109(2.4) & .190(3.8) & .084(1.8) \\ \text { WTEXP } & .039(0.3) & .007(0.1) & .045(0.3) & .104(0.7) \\ \text { WTMA } & . .088(1.8) & .096(2.2) & .061(1.3) & . .079(1.8) \\ \text { WTVERB } & .016(0.2) & .033(0.5) & .003(0.0) & .020(0.3)\end{array}$

"The equations estimated are analogous 10 equation (1) in Table 2 and (1w) and (1b) in Table 3 save that the mean grade 3 score on the specific test now appears on the right-hand side. See Tables 2 and 3 for variable definitions. 
Tables

Scbool Level Synthetic Gais Score Equations: Grades 9 to 12

(absolute value $t$ statistios)

\section{All Students}

White Students

Blaçk Studeds

\begin{tabular}{|c|c|c|c|c|c|}
\hline & (1) & (1) & (1w) & (1) & (1b) \\
\hline INTER & $2.405(0.7)$ & $4.161(0.8)$ & $6.706(1.2)$ & $4.013(0.8)$ & $.13 .326(1.4)$ \\
\hline FEM & $-.021(1.4)$ & $-.036(2.0)$ & $-.031(1.8)$ & $-.012(0.5)$ & $.021(0.8)$ \\
\hline BLACKS & $=.025(1.2)$ & $.057(2.0)$ & $.063(2.2)$ & $-.002(0.1)$ & $.017(0.5)$ \\
\hline FNHH & $-.099(3.6)$ & $-.129(3.1)$ & $-.139(3.3)$ & $.085(25)$ & $-.076(2.3)$ \\
\hline $\mathrm{MNHH}$ & $-.059(1.2)$ & $-.044(0.6)$ & $.056(0.8)$ & $-.056(1.0)$ & $-.047(0.8)$ \\
\hline PHONE & $.054(3.3)$ & $.004(0.1)$ & $.005(0.2)$ & $.064(3.2)$ & $.064(3.2)$ \\
\hline INCOME & $.695(2.6)$ & $.719(2.2)$ & $802(2.4)$ & $.888(1.8)$ & $.978(2.0)$ \\
\hline FLNCH & $.007(0.4)$ & $-.043(1.5)$ & $-.049(1.7)$ & $.023(1.6)$ & $.036(1.7)$ \\
\hline FED & $.773(2,1)$ & $.694(1.5)$ & $.741(1.6)$ & $1.603(2.5)$ & $1.488(2.2)$ \\
\hline MED & $541(1.3)$ & $1.268(2.3)$ & $1.125(2.0)$ & $.849(1.4)$ & $-.754(1.2)$ \\
\hline CITY & $.138(0.3)$ & $.255(0.4)$ & $.496(0.8)$ & $204(0.3)$ & $-.060(0.1)$ \\
\hline RURAL & $.328(0.7)$ & $-.063(0.1)$ & $-.031(0.1)$ & $.556(0.8)$ & $.645(1.0)$ \\
\hline BOOKS & $.028(0.6)$ & $.004(0.1)$ & $.022(0.4)$ & $-.031(0.4)$ & $.097(1.2)$ \\
\hline PUPT & $.088(2.1)$ & $.054(1.1)$ & $.051(1.0)$ & $.006(0.9)$ & $.017(0.2)$ \\
\hline BYTEST & $-.556(14.7)$ & $-.621(12.2)$ & $-.612(12.1)$ & $-544(9.4)$ & $-553(9.7)$ \\
\hline BLACKT & $-2.578(1.4)$ & $.10 .177(2.4)$ & $10.627(0.3)$ & $.089(0.0)$ & $22.949(2.2)$ \\
\hline EXP & $.023(0.4)$ & $-.000(0.0)$ & & $.020(0.2)$ & \\
\hline $\mathrm{MA}$ & $-.011(1.1)$ & $.017(1.4)$ & & $.035(1.9)$ & \\
\hline VERB & $.081(2.5)$ & $.104(2.4)$ & & $-.008(0.2)$ & \\
\hline BTEXP & & & $-.671(1.1)$ & & $-.061(0.6)$ \\
\hline BTMA & & & $.335(2.0)$ & & $.057(2.5)$ \\
\hline BTVERB & & & $-.233(0.6)$ & & $-.046(0.8)$ \\
\hline WTEXP & & & $.008(0.1)$ & & $321(1.7)$ \\
\hline WTMA & & & $-.025(1.9)$ & & $.004(0.1)$ \\
\hline WTVERB & & & $.092(2.2)$ & & $.176(1.5)$ \\
\hline 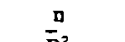 & 256 & 178 & 178 & 183 & 183 \\
\hline $\mathbf{R}^{2}$ & .488 & .470 & .480 & .360 & 378 \\
\hline
\end{tabular}

- See Tables 2 and 3 for variable definitions. BYTEST is now the mean grade 9 test score (percentage of correct answers) in the school. 
Table 6

Comparison of WLS and WTV Estimates of School Level Synthetic Gain Score Equations: Grades 3 to $6^{*}$ (absolute value $t$ statistics)

\begin{tabular}{c|c} 
(WLS) $^{\text {b }}$ & $($ WTV \\
\hline
\end{tabular}

(1)

(2)

(3)

\begin{tabular}{crrr}
\hline BOOKS & $.010(0.3)$ & $.064(1.4)$ & $.479(1.3)$ \\
PUPT & $.081(2.3)$ & $-.392(3.0)$ & $-.415(2.3)$ \\
BLACKT & $-4.195(3.8)$ & $-3.922(2.9)$ & $7.684(1.1)$ \\
EXP & $.068(2.0)$ & $.039(0.9)$ & $.105(0.5)$ \\
MA & $.004(0.3)$ & $-.219(4.6)$ & $-.284(3.9)$ \\
VERB & $.093(4.1)$ & $.098(3.6)$ & $.448(2.1)$ \\
\hline
\end{tabular}

all equations also contain all of the variables used in column (1) of Table 2.

${ }^{\circ}$ Coefficients from Table 2, column (1).

Instrumental variable estimates - estimates in column (2) use instruments for MA and PUPT only, while the estimates in column (3) use instruments for all six variables. 
Table 7

Difference in Difference Estimators: White Student Minus Black Student Synthetic Gain Equations, Grades 3 to 6

(absolute value $\mathbf{t}$ statistic

(1)

\begin{tabular}{ccc}
\hline BOOKS & $-.148(1.3)$ & $-.140(1.2)$ \\
PUPT & $.071(0.7)$ & $-.028(0.3)$ \\
BLACKT & $-16.556(5.2)$ & $-32.438(2.8)$ \\
EXP & $.261(2.4)$ & \\
MA & $.021(0.6)$ & \\
VERB & $.112(1.7)$ & $.022(0.1)$ \\
BTEXP & & $-.151(1.7)$ \\
BTMA & & $.325(2.6)$ \\
BTVERB & & $.269(2.2)$ \\
WTEXP & & $.053(1.5)$ \\
WTMA & & $.015(0.2)$ \\
WTVERB & & 353 \\
nT & 353 & .30 \\
\hline R & .29 & \\
\hline
\end{tabular}

"Also included in each equation are all of the variables used in column (1) of Table 2. Each equation is estimated by weighted least squares, with the weight being $\left(W_{W} \times W_{B}\right) /\left(W_{W}+W_{B}\right)$ where $W_{W}$ and $W_{B}$ are the weights used for white and black students respectively (see Table 2). 
Table 8

Estimated Cbanges in Galn Scores trom Chaages in

Teacber Race and Verbal Abllity

Grades 3 to 6

Grades 9 to 12

\begin{tabular}{llllllll}
\hline \multicolumn{3}{c}{ White Students } & \multicolumn{3}{c}{ Black Students } & Wblte & Black \\
\hline (1W) & (3W) & (5W) & (1B) & (3B) & (5B) & (1W) & (1B) \\
\hline
\end{tabular}

1) Increase the Fraction of

$\begin{array}{lllll}-1.20 & -1.09 & -.79 & -.27 & -.23\end{array}$

$\begin{array}{ll}-.36 & -.95\end{array}$

21

Black Teachers by .1

(bolding constant all

otber teacher

characteristics)

2) Inerease the Fraction of

.74

$-.24$

$-.25$

$-.47 \quad-.93$

37

Black Teachers by .1

(assuming black and

white teachers both bad

the mean characteristics

of black teachers)

3) Increase the fraction of .98

Black Teachers by .1

(assuming black and

white teachers both had

the mean characteristics

of white teachers)

4) Increase the Verbal Aptitude Scores of Black

.15

.14

.12

.95

.97

$.80 \quad-.00$

.04

Teachers by 10 Point

5) Increase the Verbal

Aptitude Scores of

.45

.50

.24

.$\infty 6$

.04

$-.20$

.09

.04

White Teachers by 10

Points

Source: Authors' calculations from data in Table 1 and coefficienl estimates in the indicate columns from Table 3 (for grades 3 to 6) and Table 5 (for grades 9 to 12). 
Appendix Table Al

Scbool Level Mean Test Score Equations: Grades 3, 6, 9, and 12 (absolute value t statistics)

\begin{tabular}{|c|c|c|c|c|}
\hline & GRADE 3 & GRADE 6 & GRADE 9 & GRADE 12 \\
\hline INTER & $38.998(2.8)$ & $25.031(8.3)$ & $17.646(3.1)$ & $4.119(1.0)$ \\
\hline FEM & $-.018(0.9)$ & $.053(2.6)$ &. $.094(3.6)$ & $-.031(1.9)$ \\
\hline BLACKS & $-.075(7.3)$ & $-.095(8.9)$ & $-.059(1.7)$ & $-.047(1.9)$ \\
\hline FNHH & $-.056(2.9)$ & $.085(4.2)$ & $-.221(5.3)$ & $-.219(6.7)$ \\
\hline $\mathrm{MNHH}$ & $.071(2.6)$ & $-.257(9.0)$ & $-.139(1.8)$ & $-.138(2.2)$ \\
\hline PHONE & $.077(5.8)$ & $.129(9.2)$ & $.051(2.0)$ & $.077(3.7)$ \\
\hline INCOME & $.059(0.3)$ & $.200(1.0)$ & $1.634(3.9)$ & $1.511(4.6)$ \\
\hline FLNCH & $-.028(2.5)$ & $-.039(3.2)$ & $.009(0.3)$ & $.002(0.1)$ \\
\hline FED & $.854(3.7)$ & $1.386(5.7)$ & $1.440(2.4)$ & $1.515(3.2)$ \\
\hline MED & $.639(2.2)$ & $.606(2.0)$ & $.329(0.5)$ & $.799(1.4)$ \\
\hline CTIY & $-3.161(6.6)$ & $-1.764(3.6)$ & $-2.074(2.5)$ & $.470(0.8)$ \\
\hline RURAL & $\cdot .131(0.3)$ & $1.039(2.1)$ & $.091(0.1)$ & $.502(0.8)$ \\
\hline BOOKS & $.003(0.1)$ & $.007(0.2)$ & $.069(1.0)$ & $.064(1.2)$ \\
\hline PUPT & $-.134(3.9)$ & $-.121(3.3)$ & $-.053(0.8)$ & $.074(1.4)$ \\
\hline BLACKT & $2.904(2.6)$ & $.2 .824(2.4)$ & $1.518(0.5)$ & $-1.075(0.5)$ \\
\hline EXP & $.133(3.8)$ & $.111(3,1)$ & $.016(0.2)$ & $.071(1.0)$ \\
\hline MA & $-.017(1.5)$ & $-.013(1.1)$ & $-.010(0.6)$ & $-.030(2.4)$ \\
\hline VERB & $.048(2.1)$ & $.108(4.5)$ & $.152(2.9)$ & $.165(4.1)$ \\
\hline I & 969 & 969 & 256 & 256 \\
\hline$\overline{R^{2}}$ & .701 & .886 & .881 & .932 \\
\hline
\end{tabular}

-All variables are defined as in Table 2. 


\section{Appendix Table $\mathbf{A 2}$}

Estimation of Instrumental Variable Equations

(absolute value of $t$ statistics)

\begin{tabular}{|c|c|c|c|c|c|c|}
\hline & BOOKS & PUPT & BLACKT & EXP & MA & VERB \\
\hline DNTER & $-8.139(0.5)$ & $56.248(3.2)$ & $1.392(2.5)$ & $-16.275(1.1)$ & $.57 .792(1.2)$ & $3.355(0.1)$ \\
\hline FEM & $.029(1.8)$ & $-.021(1.2)$ & $.000(0.7)$ & $.017(1.1)$ & $.054(1.1)$ & $.004(0.1)$ \\
\hline BLACKS & $-.022(4.0)$ & $.027(4.4)$ & $.008(38.6)$ & $-.010(2.1)$ & $.027(1.6)$ & $-.118(13.2)$ \\
\hline FNHH & $-.005(0.3)$ & $-.018(1.0)$ & $.002(2.7)$ & $.033(2.2)$ & $.104(2.1)$ & $.047(1.8)$ \\
\hline MNHH & $-.029(1.4)$ & $.010(0.5)$ & $.003(3.6)$ & $.035(2.0)$ & $-.198(3.3)$ & $-.158(5.9)$ \\
\hline PHONE & $.007(0.6)$ & $-.006(0.4)$ & $-.001(33)$ & $.013(1.2)$ & $.045(1.3)$ & $.084(4.4)$ \\
\hline DNCOME & $-.369(1.8)$ & $.276(1.3)$ & $.030(4.5)$ & $-.175(1.0)$ & $1.109(2.0)$ & $-.402(1.3)$ \\
\hline FLNCH & $.006(0.5)$ & $.023(2.2)$ & $-.001(1.3)$ &. $.017(1.9)$ & $.021(0.7)$ & $.020(1.3)$ \\
\hline FED & $.421(2.2)$ & $-.260(1.0)$ & $.002(0.3)$ & $-.198(1.1)$ & $-.561(1.0)$ & $.193(0.6)$ \\
\hline MED & $.194(0.7)$ &. $.261(1.0)$ & $.015(1.7)$ & $.381(1.7)$ & $1.284(1.7)$ & $.527(1.3)$ \\
\hline CITY & $-.922(2.1)$ & $.991(2.1)$ & $-.120(8.1)$ & $-.707(1.9)$ & $.403(0.3)$ & $3.325(5.0)$ \\
\hline RURAL & $.016(0.3)$ & $-.921(2.1)$ & $.007(0.5)$ & $-.538(1.5)$ & $.382(0.3)$ & $-.146(0.2)$ \\
\hline ESAL & $2.066(1.8)$ & $-3.880(1.8)$ & $-.146(2.2)$ & $3.824(2.3)$ & $7335(1.3)$ & $6.708(2.2)$ \\
\hline POP & $.003(2.3)$ & $-.006(3.2)$ & $.000(1.8)$ & $-.001(0.6)$ & $-.006(1.4)$ & $-.008(3.1)$ \\
\hline POPDEN & $.000(1.3)$ & $-.001(2.1)$ & $-.000(6.1)$ & $.000(0.5)$ & $.005(4.9)$ & $.001(2.2)$ \\
\hline PURB & $-.004(0.3)$ & $.013(1.0)$ & $.001(2.9)$ & $-.004(0.4)$ & $.104(2.7)$ & $-.062(3.0)$ \\
\hline PBLK & $.003(0.2)$ & $.051(3.4)$ & $.002(5.0)$ & $-.004(0.3)$ & $-.074(1.8)$ & $-.095(4.3)$ \\
\hline P650 & $-.357(3.7)$ & $.088(0.9)$ & $.010(3.0)$ & $.191(2.3)$ & $-.031(0.1)$ & $.346(2.3)$ \\
\hline MEDU & $-.541(1.5)$ & $.969(2.5)$ & $.013(1.0)$ & $.514(1.6)$ & $-.415(0.3)$ & $.341(0.5)$ \\
\hline PGHS & $.058(0.9)$ & $-.103(1.6)$ & $.002(0.8)$ & $-.123(2.2)$ & $.010(0.1)$ & $.070(0.7)$ \\
\hline SEN & $-.011(2.0)$ & $.002(3.6)$ & $.000(2.0)$ & $.009(1.9)$ & $.043(2.8)$ & $.027(3.2)$ \\
\hline PWHC & $.072(1.6)$ & $\cdot .088(1.8)$ & $.003(1.8)$ & $.056(1.3)$ & $.164(1.2)$ & $.008(0.1)$ \\
\hline MINC &. $.686(2.2)$ & $.859(2.5)$ & $-.056(5.2)$ & $-.737(2.7)$ & $-5.227(5.7)$ & $1.629(3.3)$ \\
\hline PUBAS & $-.033(2.3)$ & $.027(1.8)$ & $.001(1.9)$ & $.034(2.7)$ & $-.093(2.2)$ & $.042(1.9)$ \\
\hline PSEE & $.724(0.2)$ & $-4.468(1.5)$ & $.251(27)$ & $-3.883(1.6)$ & $6.749(0.9)$ & $-3.356(0.8)$ \\
\hline$\overline{\mathbf{R}^{2}}$ & .148 & .207 & .870 & .134 & .156 & .644 \\
\hline $\mathrm{D}$ & 889 & 888 & 1129 & 1129 & 1129 & 1129 \\
\hline
\end{tabular}

"Weighted least squares regessions. The weights used in each case are the number of teachers taking the test.

${ }^{-}$Coefficient bas been multiplied by 1000 . 


\section{Appendix Table $\mathbf{A}$ (continued)}

ESAL estimated starting salary of teachers in the district

POP area population is 1960

POPDEN area population per square mile in 1960

PURB percent area population living in urban areas in 1960

PBLK percent area population that is black in 1960

P650 percent area population that is age 65 or older

MEDU median school years completed for area population that is age 25 or older in 1960

PGHS percent area population 25 or older in 1960 that completed bigh school

SEN total area school enrollmeat in 1960

PWHC percent area adults in white collar jobs in 1960

MINC . median family income in the area in 1960

PUBAS percent area families on public assistance in 1964

PSEE per student school expenditures in the area in 1960

All other variables are defined in Table 2.

Sources: a) Aurhors' computations from the Equality of Educational Opportunity survey data tapes.

b) Authors" computations from the 1965 Ciry and County Databook data tape. The "area" refers to the SMSA in which the school is located, if the school is in an SMSA and the county in which the school is located for schools out side SMSAs. 


\section{Data Appendix \\ 'DID TEACHERS' RACE AND VERBAL ABILITY MATTER \\ IN THE 1960'S: COLEMAN REVISITED?"}

by

Ronald G. Ehrenberg and Dominic J. Brewer

This appendix briefly describes the methods used to construct the data used in this study; further details, including computer programs, are available upon request.

\section{Student Data}

The EEO data tapes contain responses from 135,750 grade 3 students, 125,170 grade 6 students, 134,030 grade 9 students, and 97,660 grade 12 students. For each student, the percentage of correct responses on each of four tests (verbal, nonverbal, reading, mathematics) was calculated, and a simple average of these four tests used for the test score. (A fifth, "general information" test administered to 9 th and 12 th graders was not used.)

School means of all student variables were then calculated. These means could be calculated for 2,499 grade 3 schools, 2,389 grade 6 schools, 930 grade 9 schools, and 787 grade 12 schools. The mean test scores used are based on an average of 52 students for grades 3 and 6, and 124 students for grades 9 and 12. To calculate the gain score for a school, both grade 3 and grade 6 mean test scores, or grade 9 and grade 12 mean test scores, were required. This further reduced the sample sizes, especially for grades 9 and 12 , since many 9 th graders were enrolled in junior high schools rather than high schools. Nonmissing responses for at least some students on all the variables that were used in the regression analyses, also were required, which further reduced the sample sizes. For grades 
3 and 6, grade 6 student responses were used to compute the school means for student and family characteristics, while for grades 9 and 12 , grade 12 student responses were used.

An estimate of the mean income of families in a school was calculated by matching data on regional (North Central, North East, West, South) median male earnings by occupation from the 1970 Census of Population (Vol. 1, Pt. 1, Sect. 2, Table 296) to each student's father's occupation and then computing school-wide mean values of these medians.

Unless otherwise stated, all tested students are used in the calculation of the gain scores. However, in Table 2 for those "students who never changed schools" (columns 4 and 5), all grade 3 and 6 students who responded "one-only this school" to the question "How many different schools have you gone to since the first grade?" were used. Altbough in principle a similar analysis could be repeated for grades 9 and 12, the reliability of such an analysis is reduced considerably given the lack of clarity in the analogous question used in the EEQ for those students which was "About how many times have you changed schools since you started the first grade (not counting promotions from one school to another)?". Less than $20 \%$ of 9 th and 12 th graders answered "never" to this question and the number of schools for which mean gain scores could be computed was too small to provide a usable sample.

It should be stressed that typically the coding of responses for various variables was not explicit in the "codebook" supplied by the National Archive to us. Hence, considerable care was taken by us to check the range of responses and tape positions, with the particular item numbers. 
Each school in the EEQ data is identified by an 11 digit "USOE" code. The first digit indicates the region and the second and third, the state in which the school was located. We were able to identify the SMSA or county in which the school was located using the state codes, the fourth, fifth, and sixth digits of the USOE code, and the ICPSR listings of SMSAs and counties in each state in 1960. Having identified each school's SMSA or county location, data was then merged into the school's record from the 1965 Ciry and County Databook.

\section{School Characteristics}

School characteristics variables were obtained from the principals file. There were 4,081 principals surveyed and about 3,900 valid responses were received. Outlier values of the pupil/teacher ratio were eliminated by us for the elementary grades analysis whenever the pupil/teacher ratio that we computed was less than 10 or greater than 50 in a school. These exclusions increased the statistical significance of the pupil/teacher ratio in our analysis but did not influence the coefficients of other variables.

\section{Teacher Characteristics}

Teacher characteristics were obtained from the 44,193 teacher responses. EEO originally contained data on 66,826 teachers, but two tape reels were lost prior to deposit at the National Archive. Mean teacher characteristics could be calculated for only 2,075 schools. 
The distributions of the numbers of black and white teachers present in the samplefor each school are found in Table DA1 for the elementary and high school samples. In a substantial number of cases, the mean values of the characteristics of black teachers in a school had to be computed based on a sample of 5 or less teachers. For example, this occurred in the overall high school sample for 55 of the 158 schools in which black teachers were present. Similarly, it occurred in 243 of the 486 elementary schools in which black teachers were present. As a result, the sampling error in the black teacher mean characteristics variables are likely to be very large which reduces our chances of obtaining statistically significant black teacher effects. 
Table DA1

\section{Numbers of Teachers}

\section{A) Secondary School Samples}

1) All Students:

\begin{tabular}{|c|c|c|c|c|}
\cline { 2 - 5 } \multicolumn{1}{c|}{} & \multicolumn{4}{c|}{ Black Temers } \\
\hline White Teachers & 0 & $1-2$ & $3-5$ & $>5$ \\
\hline 0 & 0 & 0 & 4 & 81 \\
\hline 1.2 & 1 & 0 & 0 & 11 \\
\hline $3-5$ & 5 & 1 & 0 & 0 \\
\hline$>5$ & 102 & 38 & 12 & 11 \\
12 \\
6 \\
163 \\
266 \\
\hline
\end{tabular}

2) Black Students:

\begin{tabular}{|c|c|c|c|c|}
\cline { 2 - 5 } \multicolumn{1}{c|}{} & \multicolumn{4}{c|}{ Black Teachers } \\
\hline White Teachers & 0 & $1-2$ & $3-5$ & $>5$ \\
\hline 0 & 0 & 0 & 4 & 81 \\
\hline $1-2$ & 0 & 0 & 0 & 11 \\
\hline $3-5$ & 2 & 0 & 0 & 0 \\
\hline$>5$ & 41 & 28 & 10 & 11 \\
\hline 11 \\
2 \\
90 \\
\hline
\end{tabular}

3) White Students:

\begin{tabular}{|c|c|c|c|c|}
\cline { 2 - 5 } \multicolumn{1}{c|}{} & \multicolumn{4}{|c|}{ Black Teachers } \\
\hline White Teachers & 0 & $1-2$ & $3-5$ & $>5$ \\
\hline 0 & 0 & 0 & 0 & 15 \\
\hline $1-2$ & 1 & 0 & 0 & 3 \\
\hline $3-5$ & 5 & 1 & 0 & 0 \\
\hline$>5$ & 101 & 37 & 12 & 10 \\
4 \\
6 \\
160 \\
185
\end{tabular}


B) Elementary School Samples

1) All Students:

\begin{tabular}{|c|c|c|c|c|}
\cline { 2 - 5 } \multicolumn{1}{c|}{} & \multicolumn{4}{|c|}{ Black Teacbers } \\
\hline White Teachers & 0 & $1-2$ & $3-5$ & $>5$ \\
\hline 0 & 0 & 27 & 32 & 149 \\
\hline $1-2$ & 34 & 1 & 1 & 25 \\
\hline $3-5$ & 69 & 6 & 2 & 13 \\
208 \\
61 \\
90 \\
639 \\
\hline$>5$ & 409 & 128 & 46 & 56 \\
998
\end{tabular}

2) Black Students:

\begin{tabular}{|c|c|c|c|c|}
\cline { 2 - 5 } \multicolumn{1}{c|}{} & \multicolumn{4}{|c|}{ Black Teachers } \\
\hline White Teachers & 0 & $1-2$ & $3-5$ & $>5$ \\
\hline 0 & 0 & 28 & 31 & 147 \\
\hline $1-2$ & 3 & 0 & 1 & 26 \\
206 \\
30 \\
29 \\
268 \\
\hline$>5$ & 11 & 5 & 1 & 12 \\
54 & 82 & 39 & 53 \\
533
\end{tabular}

3) White Students:

\begin{tabular}{|c|c|c|c|c|}
\cline { 2 - 5 } \multicolumn{1}{c|}{} & \multicolumn{4}{c|}{ Black Teachers } \\
\hline White Teachers & 0 & $1-2$ & $3-5$ & $>5$ \\
\hline 0 & 0 & 2 & 6 & 60 \\
\hline $1-2$ & 33 & 0 & 1 & 14 \\
\hline $3-5$ & 69 & 6 & 2 & 7 \\
\hline$>5$ & 406 & 128 & 43 & 43 \\
48 \\
84 \\
620 \\
820
\end{tabular}

